\title{
RESEARCH AND EDUCATION IN AGROBUSINESS IN MOSONMAGYARÓVÁR - THE 200-YEAR HISTORY
}

\author{
Judit Hegyi \\ Széchenyi István University, Faculty of Agricultural and Food Sciences, \\ Department of Agricultural Economics and Rural Development \\ Vár Sqr. 2, H-9200 Mosonmagyaróvár \\ hegyi.judit@sze.hu
}

\begin{abstract}
In 2018, the Faculty of Agricultural and Food Sciences of Széchenyi István University celebrated the bicentenary of its predecessor's foundation. Agrobusiness courses played an important role in the university's agricultural engineering program throughout this major time period. The aim of this study is to examine how the titles, the content, and the significance of the courses changed during the institution's important periods. Institutional history publications and the academic textbooks of great professors provided the basis of this research. Business administration, accounting, and agricultural estimation studies courses were already dominant in the first curricula. Later, courses concerning business and agricultural economics gained more ground and were accompanied by other fields of study: agricultural statistics, agricultural politics, agricultural history, and agricultural economics. During this 200-year period, the education of economics and other social science courses was done within the departments of agricultural economics and marketing, work organization and factory management, and social science and business operations, with the contribution of internationally renowned professors: Pál Sporzon, Richárd Suschka, Árpád Hensch, Károly Világhy. The Hungarian Royal Economics Academy (1874-1942) can be considered as the first prime of the agricultural economics education. From the 1900s onwards, the courses became more specialized, their numbers continuously grew, the disciplines expanded, and the number of departments increased. The second prime is the first decade of the 2000s, when besides the traditional agricultural programs, the institution started teaching economic agricultural engineers in its undivided 5-year training. They were the most popular agricultural engineers in the labor market due to their well-balanced knowledge in agriculture and economics, as well as their excellent leadership skills.

Having abandoned the economic agricultural engineering program, the institution currently educates, besides other agricultural majors, rural development agricultural engineers, whose skills the labor market does not know very well. The proportion of business related courses show a significant decline in the curriculum of traditional agricultural programs as well.
\end{abstract}

Keywords: Széchenyi István University, agricultural higher education in Magyaróvár, bicentenary, agricultural engineering program, agro-economics, rural development

(JEL Classification: N30 )

\section{INTRODUCTION}

Following the regime change of 1989 in Hungary, within the national economy sectors, agriculture was the one that changed the most. Consequently, the evolving of the agricultural sector and the need for the reformation of agricultural education is continuously on the agenda. The international practice of agricultural training programs shows that universities and research institutes that are active in several different disciplines and have a great student body can provide competitive knowledge for its students. The agricultural higher education institute of Mosonmagyaróvár, the first such institution in Europe, operated in several forms. In accordance with the above claim, in 2016, the institute merged with Széchenyi István University, which represents a varied number of disciplines. It celebrated the bicentenary anniversary of the foundation of its predecessor as the Faculty of Agricultural and Food Sciences of the university. The history of the 200-year-old institute has been studied from many different angles by many scholars. The first comprehensive study is the work of Árpád Balás, former principal of the institute. In his book, published in 1987, Balás told the history of the first 80 years of the institute, which was in its fourth "era" at the time, by embedding it into the history of the 
Hungarian higher education of agricultural studies. Partially this book, and partially Sándor Bánvárt’s 1927 book provided the basis for two institutional history books: one written for the 150th anniversary of the foundation of the Private Institute by Antal Vörös, and one written for the 175th anniversary by Gyula Walleshausen. Antal Tenk finished his book, titled Dicső múltunk, for the bicentenary year, which presents 200 years of history with an emphasis on the biographies of great professors. The changes in the content and emphasis in the courses of agricultural higher education can be traced with the help of historic works. Courses related to agro-economics, as well as the materials of business administration and leadership has been present on the educational palette of the institution. In connection with the jubilee, the long time period allows for the examination of the role and contents of the research and education of agro-economics and rural development in contrast to core subjects like cultivation, livestock breeding, and other foundational courses.

\section{MATERIAL AND METHODS}

The research is based on books published for jubilees, books concerning the history of the institute, as well as academic textbooks written by significant figures of business studies. Analysis is also based on primary sources such as original curricula and course descriptions.

The structure of the paper follows the eras of the institution with special emphasis on important milestones. The following domains were developed after the general characterization of the institutional era (length of program, language of program, title of qualification, and the heads of the institute):

- what titles are given to the agro-economic and rural development courses in the curriculum

- within what kind of organizational framework does the teaching of the courses occur

- which significant professors are connected to the research and teaching of agro-economics, along with their most important academic textbooks

- the hours appointed to the examined courses in the timetable

- the proportion of agroeconomic courses compared to other courses

Based on the analysis, those time periods were highlighted that proved to be the most significant regarding the education of agroeconomic courses.

\section{RESULTS END DISCUSSION}

Magyar-Óvári Gazdasági Magántanintézet (1818-1849) Private Institute of Economics of Magyar-Óvár

The language of the 2-year long program is Latin-German, the title of the qualification: farm officer. The head of the institute between 1818 and 1832 was Antal Wittmann, a landsteward of the estate and founding member of the institute, between 1833 and 1849 Joachim Keyle was the principal (Kalmár and Orbán 2017). The private institute is funded by the revenue of the estates.
When Antal Wittman became the land-steward of Prince Albert Casimir of Saxony-Duke of Teschen's estates in 1811, he already formed the clear notion that a rationally functioning large-scale plant necessitates a highly educated leadership. He also understood that such a leadership could only be provided by organized education. Thus in 1816, only two years after his arrival to Magyaróvár, he already proposed the establishment of a higher educational institution in Magyaróvár to Albert Casimir. The educational institution, officially opening on November 10, 1818, started operating in the building of the castle. The first academic year opened with 4 teachers and 22 students (Tenk, 2017).

In the beginning, the curriculum was temporary and only for internal use. The first official curriculum was published by the institute on September 1, 1820. According to the announcement, the winter semester was to start on November 1 , and only the courses and weekly number of lessons of that semester were fixed. The courses did not include any related to economics, however, "the lectures of accounting were held separately in the finance offices of the estate, where the process of accounting was introduced in practice as well" (Walleshausen, 1993).

Thear Albrecht (1752-1828) laid down the foundations of livestock equipment and - management studies in his 1809 school founding work, published in Germany. He gained several followers in the same century, both in Germany and Hungary.

Császári és Királyi Gazdasági Felsőbb Tanintézet (18501869) - Imperial and Royal Economics Higher Education Institution

Similarly to the previous one, the length of the program is 2 years, the language of the program is German, and the title of qualification is farm officer. The heads of the institute: 1850-1861, Dr. Vilmos Henrik Pabst, principal; 1861-1884: Dr. Antal Masch, principal (Kalmár and Orbán 2017).

At the end of 1849, after the events of the Hungarian Revolution of 1848, the Ministry of Landeskultur in Vienna ordered the establishment of a state-owned economics higher education institution in the territory of the Monarchy. Following several proposals, the imperial decree, signed on March 22, 1850, officiated the transfer of ownership of the institute from private to state. The new institutional code stated that the institution was directly under the purview of the ministry (Tenk, 2017).

The first organizational regulation, published in 1850, only defined the curriculum of the theoretical disciplines and their weekly lesson numbers, without breaking it down into school years. Among the courses we can find ones that are presented for the first time in Óvár: national economics studies, foundations of legal studies, agricultural law, and government organization studies, which later developed into the discipline of public administration studies (Walleshausen, 1993). Three of the core subjects gained titles: in three hours a week, accounting, in four hours a week, business administration, and in 3-4 hours a week, national economics studies. Courses of legal nature were grouped with subsidiary subjects. Vencel Hecke (18241900) was appointed as a professor in 1857. A native of Óvár, after long vicissitudes, he enrolled in the institute in 1851 . He 
graduated with a scholarship in 1853 with excellent marks. As an assistant lecturer, he taught technology and silk cultivation, as a professor, however, he taught general and detailed plant cultivation, business administration, and estimation studies. A new course appeared in the 1860 curriculum: regional agricultural conditions. The lecturer, Hecke (then Hitschmann and Reitmann), describes the region's agricultural attributes (climate, soil, produces, population, farms, etc.). With this studium, "tájtermelés" enters the education scene, which we can regard as the predecessor of rural development studies, and it appears in the curriculum for the next one and half decade. (The textbook, which was also used for teaching business administration, was written by Hecke). During Pabst's (1798-1868) years as principal, he published seven academic textbooks, and the first part in the fourth volume of the Agriculture textbook is: Agrobusiness studies. (The concept of business administration replaced agrobusiness studies only in the 1880s). From 1855, István Morócz (1816-1881), László Korizmics (1816-1886), and Dániel Benkő (1799-1883) applied the Stephens Henri's The Book of the Farm to the Hungarian conditions in seven volumes. The 6th volume, titled Livestock Equipment, was published in 1868.

The Hungarian National Association of Economics supported the publication of several statistical works concerning livestock equipment through the introduction of estates such as Mágocs, Kis-Jenô, Béllye.

Magyar Királyi Gazdasági Akadémia (1874-1942) Hungarian Royal Academy of Economics

First, the length of the program was 2 years (1874-1902), then 3 years (1902-1942). The language of the program was Hungarian-German between 1874 and 1884, then Hungarian from 1884. The title of qualification was farm officer (18741889), farm officer with university degree (1900-1926), engineer with university degree (1927-1930), farmer with university degree (1930-1942). The heads of the institute: between 18611884, Dr. Antal Masch, principal; 1884-1896, Dr. Árpád Balás, principal, 1897-1898 Viktor Thallmayer, commissioned principal; 1898-1907, Sándor Vörös, principal; 1907-1908, Kálmén Kerpely, commissioned principal; 1908-1909, Árpád Hensch, principal; 1909-1919, Imre Ujhelyi, principal; 19191920, Imre Rázsó, vice principal; 1920-1930, Sándor Bányárth, principal; 1930-1942, Gábor Groffits, principal (for a short period, 09.13.-10.15, 1930, Zsigmond Zalka, vice principal) (Kalmár and Orbán 2017).

By the 1860s, the thorough education of professional skills became a necessary condition for the further development of Hungarian agriculture. The training attempts of the first half of the century attest to this recognition however, except for Georgikon in Keszthely and the school in Magyaróvár, an adequate institutional background did not exist. Meanwhile, agricultural education was already happening within an organized framework in Western Europe (CSISZÁR, 2012).

After the Austro-Hungarian Compromise of 1867, the Ministry of Agriculture, Industry, and Commerce started operating on March 10, 1967, and it took control of maintaining the institution in Magyaróvár in 1969. During this period, higher education institutions in Debrecen, Keszthely, and
Kolozsmonostor were operating as well, but their opening and operation did not cause any particular issues for the ministry (Tenk, 2017).

Since the 1890s, a growing number of people had been concerned with reforming the higher education program of agriculture. Győrgy Linhart, professor of the Academy, turned to the public and particularly to the ministry with concrete suggestions that mostly focused on the rearrangement of the institutional framework while also taking into consideration the reform of the program itself. Linhart assumed a great role in the creation of a curriculum that set higher requirements for academies (Linhart, 1900).

In the first curriculum of the academy, the following economic courses appeared: local economic conditions, agrobusiness studies, accounting, national economic studies, estimation studies (Photo 1.) The most important professors of this era: Pál Sporzon (1831 - 1917) (Agricultural Accounting, Economic Estimation Studies, Agricultural Business Administration), Richárd Suschka (1858 - 1910) (Basic Agricultural Accounting), Árpád Hensch (1847 1913) (Agricultural Business Administration I-II, Livestock Equipment and Management Studies). Their textbooks targeted a niche in this field of education. Pál Sporzon in the introduction of his 1885 book titled "Gazdasági becsléstan" (Economic Estimation Studies) mentions the following as the essential basis for successful business: business administration, as determiner of reasonable business conditions, accounting studies, as the indicator of the degree of profitability, while estimation studies as the indicator of the of return capability of income sources. He advises the careful study of these for all farmers. ÁRPÁD HENSCH emphasizes in his 1906 book, Agricultural Business Administration I-II: "virtually, the task of livestock equipment and management studies is to determine those business ratios and economic guiding principles in the equipment and management of farms that one should follow to ensure the largest constant pure revenue in the organization and leading of production. Additionally, the central idea of these principles is to achieve the most favorable ratio of production income and productions costs." (Photo 2.)

Photo 1.

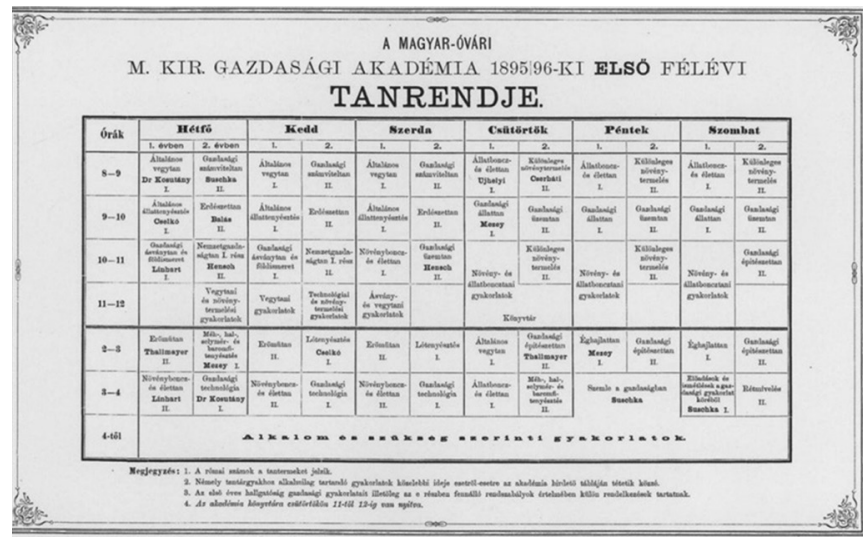

Source: the notice of the Hungarian Royal Academy of Economics, 1895 
Photo 2.

\section{MEZ̈̈GAZDASÁGI ÜZEMTAN}

MÁSODIK KÖTET<smiles>CC#N</smiles>

MEZŐGAZDASÁGI BECSLÉSÉS ELÖSZÁMITÁSTAN

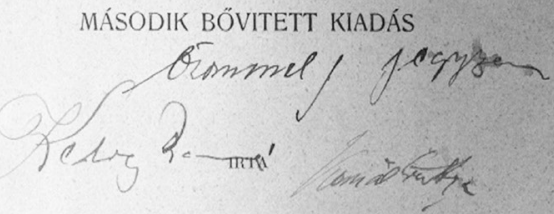

ÉS A NAGYMÉLTOSSÁGU FÖLDMIVELÉSÜGYI M. KIR. MINISZTER ÚR TÁMOGATÁSÁVAL KIADTA

HENSCH ÁRPÁD

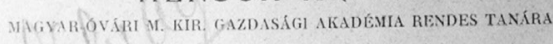

$$
\text { Mio. Mirioxi Marghom }
$$

Source: Hensch, Á. (1906): Mezôgazdasági üzemtan. Becslés és előszámítástan. Vitéz nyomda. Kassa.

After 8 decades of a 2-year program, a 3-yearlong one replaced it from 1902. Business courses are taught in the third year, out of nine subjects, 5 are of this area of studies: business administration (livestock management, livestock equipment and management), economics (agropolitics, business statistics), business accounting, business commerce studies, business public administration studies, and legal studies. The growing significance of business studies manifests in the weekly number of lessons: out of the 22 lessons of the year, 13 are business studies related. Károly Világhy (18831975) was the head of the Department of Business Administration between 1922 and 1949. His almost three decades of work provided the foundations of modern business administration studies (The Basics of Business Administration Studies). The focus of his research was the problems of the business analyses of plant cultivation (Photo 3.) He prepared several lecture notes for students, one of which was concerning dairy production business administration (1930), and it discussed the physiological and economical significance of milk.
Photo 3.

\section{A MEZÖGAZDASÁGI ÜZEMTAN}

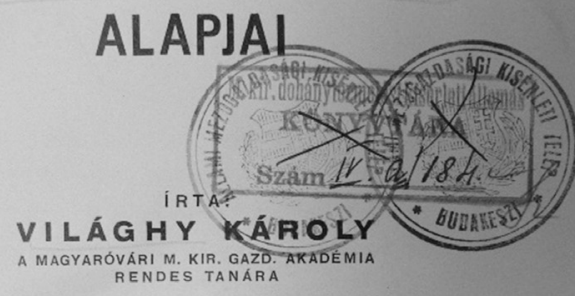

KÜLÖNLENYOMAT

A DR. BITTERA-, PESTHY. ÉS VILÁGHY-FÉLE ,MEZÖGAZDASÁGI ENCIKLOPÉDIÁ"-BÓL

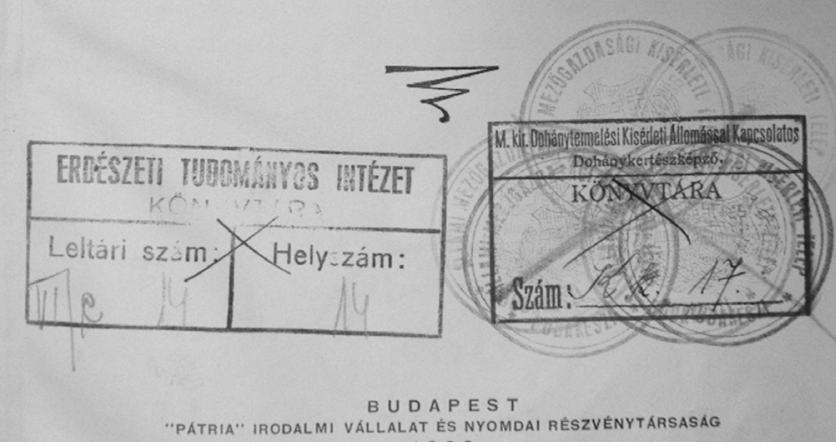

Source: Világhy K. (1930): A mezőgazdasági üzemtan alapjai. Budapest. Pátria Irodalmi Vállalat és Nyomdai Részvénytársaság.

Magyar Királyi Mezőgazdasági Főiskola (1942-1945) Hungarian Royal College of Agriculture

During this period, the length of the program was 4 years, the language of the program was Hungarian, and the title of qualification was agronomist with university degree. The head of the institute during this period (1942-45): Gábor Groffits, dean (Kalmár and Orbán 2017).

The area of economics was hosted by several departments, its significance continued to grow which manifested in the diversification of departments and courses.

Department of Agricultural Business Administration:

- Agricultural Business Administration

- Methods of Business Consulting

- Agricultural Business Administration seminar

Department of Accounting

- Agricultural and Commerce Accounting

- Agricultural Statistics

- Market Research

Department of Economics

- Economics Studies

- Agricultural Politics

- Cooperative Policies

- Agricultural Social Policies 
Legal courses also receive a separate department (Department of Civil and Commercial Law) (Walleshausen, 1993). Between 1949 and 1954, higher education was suspended in Óvár. The reopening was motivated by the then just evolving agricultural structures' need for versatile agronomists, in which regard Óvár had been in the front in previous years already. In the 1960 s, the business education of the students occurred within the Department of Applied Business Administration (offered courses: general field work practical course and business leadership practical course), furthermore, the Department of Business Administration Studies (offered courses: agricultural business administration, agricultural statistics, and agricultural accounting and finance). Later, at the end of the 1980 s, the courses were offered within the Department of Business Economics and the Department of Work Management and Business Leadership.

PannonAgrártudományiEgyetemMezőgazdaságtudományi Kar Mosonmagyaróvár (1989 - 1999) - Pannon University of Agriculture, Faculty of Agricultural Studies

The length of the program was 5 years, the title of qualifications: agricultural engineer with university degree, business agricultural engineer with university degree, food quality management-agricultural engineer with university degree. The heads of the institute: 1989 - 1994 Dr. Péter Horn, rector - Dr. Géza Kuroli, dean, Dr. Gyula Sáringer, rector - Dr. János Iváncsics, dean (Kalmár and Orbán 2017).

Business studies were hosted within a faculty frame: the Faculty of Agro-Economics consisted of the Department of Agricultural Business and Marketing and the Department of Business Administration.

Besides these two departments, the Department of Social Sciences and the Department of Work Management and Business Leadership offered courses of economics and leadership- and management studies.

After the regime change, the new path for agricultural development was based on new foundations: on the establishment of a new operating structure and the complete reorganization of the agricultural sector. Consequently, agricultural business administration and related studies turned new operating structures, the problems of scaling, and arranging the creation of farms (individual, cooperative, company) (Nábrádi et al: ed., 2008).

The importance of this period is the fact that the "business" aspect of the education of agricultural engineers evolved into a separate program. Business agricultural engineering program has been offered at the faculty since the 1995/96 school year. Almost $40 \%$ of the institute's students are enrolled in this major, which shows the significance of the program. Starting from 2000 , the program had a graduating class every year until the program was discontinued.

Nyugat-Magyarországi Egyetem Mezőgazdaságtudományi Kar Mosonmagyaróvár (2000 - 2002) és Nyugat-magyarországi Egyetem Mezőgazdaság és Élelmiszertudományi Kar Mosonmagyaróvár (2002 - 2016) - University of WesternHungary, Faculty of Agriculture (2000-2002) and University of Western-Hungary, Faculty of Agriculture and Food Sciences (2002-2016)
The length of the program: 5 years, the title of qualification: agricultural engineer with university degree. The heads of the institute: 2000 - 2002 Dr. József Koloszár, rector - Dr. Vince Ördög, dean. 2002.07.01 - 07.08 Dr. János Iváncsics, rector (deceased) - Dr.Vince Ördög, dean; 2002.07.08. 2007 Dr. Sándor Faragó, rector - Dr. Vince Ördög, dean; 2007 - 2016.12.31. Dr. Sándor Faragó, rector - Dr. Rezsố Schmidt dean.

As the number of the instructors of the field declined, the Department of Economics and other departments hosting social science courses were gradually merged together, and from 2011 onwards, these departments operated within one institute (Institute of Business Studies).

Undivided programs were discontinued in 2007, and with the introduction of the Bologna System, the divided program started in the 2005/06 school year. The Business and Rural Development undergraduate program began with a great number of students, later, the number of applicants gradually and dynamically declined (2005/06: 40 admitted students, 2015/16 10 admitted students). However, this was a nationwide trend, not only an issue of this faculty. The Rural Development graduate program operates with 3-5 students.

Széchenyi István Egyetem Mezőgazdaság- és Élelmiszertudományi Kar Mosonmagyaróvár (2016.01.01 ) - Szécheny István University, Faculty of Agriculture and Food Sciences

The length of the undergraduate program is 3 years, while the graduate program's is 2 years (later also offered as a higher-level vocational training, 2 years). The title of qualification for the undergraduate program is agricultural engineer, and for the graduate program, it is agricultural engineer with university degree. The heads of the institute: 2016.01.01 - 2016.06.30 Dr. Péter Földesi, rector - Dr. Rezsố Schmidt, commissioned dean; 2016.07.01. - Dr. Péter Földesi, rector - Dr. Éva Szalka, dean.

The Department of Agro-Economics and Rural Development obtained its name in 2016 and comprises the tasks of its preceding institutes and departments. It offers business related courses and rural development programs on all levels. In 2016, the titles of the programs changed, they no longer include the term "business." Due to the "Great Curriculum Reform" starting in 2016, the number of the courses offered by the department, and their significance within agricultural programs decreased.

Based on the institutional history analyses, we can observe that the role of agricultural economics courses in the agricultural engineering program have continuously and significantly changed in the 200 -year period. In the first period, professors relied on German literature. With the onset of the Hungarian-language program, disregarding smaller upsand-downs, the program operated with great professors and adequate textbooks in Hungarian. These textbooks targeted a niche in the field, published in several editions, they were also nationally and internationally renowned.

The first golden era of agro-economics education is the Hungarian Royal Academy of Economics (1847-1942). Starting in the 1900s, the courses became more specialized, 
their numbers increased, the field broadened, the number of departments grew.

The second golden era of economic education was the first decade of the 2000s, when the institution was producing business agricultural engineers with university degree in the 5-year undivided program. They were the most demanded agricultural engineers of the labor market, who possessed a well-balanced knowledge of agriculture and business, as well as outstanding leadership skills.

The introduction of divided programs does not support the successes of agricultural engineering education. The fast implementation, the carelessly constructed curricula, and the labor market's rejection of the rural management's expertise led to the quick decline of the programs. We can only hope that the future steps of the reconstruction of the agricultural higher education will facilitate the renewal and stabilization of agricultural engineering programs that also provide business education.

\section{ACKNOWLENDGEMENTS}

This research was supported by EFOP -3.6.3-VEKOP-16-2017-00008 project „Innovative scientific institutions in domestic agricultural higher education”.

\section{REFERENCES}

Czimber Gy. - Horváth K. (1993): A tanszékek és egységek története (1954 - 1993). Pannon Agrártudományi Egyetem Mezőgazdaságtudományi Kar

Csiszár I. (2012): A magyar agrár felsőoktatás története a neoabszolutizmus időszakától az elsô világháborúig Tanulmányok Ujváry Zoltán 80. születésnapja alkalmából / szerk. Kavecsánszki Máté Szászfalvi Márta. -Debrecen : Kapitális Kft., p. 4154. -9789630831291

Hensch Á. (1906): Mezőgazdasági üzemtan. Jószágberendezésés kezeléstan. Vitéz nyomda. Kassa.

Hensch Á. (1906): Mezőgazdasági üzemtan. Becslés és előszámítástan. Vitéz nyomda. Kassa.

Kalmár S. - Orbán J. L. (2017): A Széchenyi István Egyetem Mezőgazdaság és Élelmiszertudományi Karának gyakorlati oktatása a kezdetektôl napjainkig ACTA SCIENTIARUM TRANSYLVANICA - MÚZEUMI FÜZETEK 25:(2) 58-78.

Linhart Gy. (1900-1902): A magyarországi felsőbb gazdasági tanügy újjászervezésének kérdése. Jelentés dr. Darányi Ignácz, val.belsô t. tanácsos, földmívelésügyi m. kir. minister úr ő nagyméltóságához Francziaország, Németország, Svájcz és Ausztriában az 1897. év nyarán tett tanulmányútról. Magyaróvár.

Nábrádi A - Pupos T - Takácsné Gy.K. (2008): Üzemtan I. Szaktudás Kiadó Ház. Budapest. 14 p.
Reichenbach B. (1930): Mezőgazdasági üzemtan. A mezőgazdasági üzem berendezése és szervezése. Pátria Nyomda. Budapest.

Sporzon P. (1881): Mezőgazdasági üzlettan. Czéh nyomda. Magyar-Óvár. 11.

Tenk A. (2017): Dicső múltunk I. A Magyaróvári Gzadasági Akadémia XIX. századi fénykorszaka és nagy tanári kara (1818-1918). Tarandus Kiadó. Mosonmagyaróvár.

Tenk A. (2018): Dicsô múltunk II. A magyaróvári agrárfelsôoktatás második száz éve. A nagy átalakulások évszázad. (21918-2018) Palatia Nyomda és Kiadó Kft.

Világhy K. (1930): A mezőgazdasági üzemtan alapjai. Budapest. Pátria Irodalmi Vállalat és Nyomdai Részvénytársaság.

Vörös A. (1968): Óvár, Óvár ... - a Mosonmagyaróvári Agrártudományi Fơiskola 150 éve Mezőgazdasági Kiadó Budapest

Walleshausen Gy. (1993): A magyar agrárfelsőoktatás 175 éve (1818-1993) 
